\title{
SEXUALIDADE E ENVELHECIMENTO. MOTIVAÇÕES E DESAFIOS
} Maria do Amparo Rocha Caridade

\section{Anais do X Congresso Brasileiro de Sexualidade Humana. Porto Alegre, 2005, p. 11.}

O homem é o único ser vivo que sabe que vai morrer. Isso o angustia, ele busca para si ilusões de eternidade, como se pudesse esconder-se de sua provisoriedade. A finitude é vista por ele como uma limitação, não como o limite que é posto à vida. Olhar assim, o impede do verdadeiro crescimento rumo à maturidade e a alegria de viver. Finitude é condição humana e nela somos desafiados a encontrar saídas para os limites, encontrar motivação para manter a vida com dignidade, satisfação, prazer e sentido. Falar de envelhecimento é falar da consciência dessa finitude, da possibilidade de ser por ela desafiados e da capacidade que temos; de proceder à superação, à transformação, à metanóia e à mudança de atitude. A vida é exigente de um ascender ao mais além.

A sexualidade é constantemente desafiada no ser humano na Terceira Idade, ela terá de ser vista considerando-se os limites do corpo, mas também as potencialidades do espírito. Entraves corporais podem ser enfrentados quando existir ludicidade criativa, afeto e sentido para a relação. A grande saída, o contorno aos limites do corpo, a dialética, a transformação desejável, será encontrada na experiência vivida com afeto e criatividade. Não na exigência descabida de performances e avaliações que transformam a relação do casal, num tribunal de avaliações mais que numa possibilidade prazerosa. Isso abate a auto-estima das pessoas e a alegria da relação.

Felicidade Sexual na Terceira Idade é uma construção responsável, que tem início desde os primórdios da vida do sujeito, mas depende da acolhida que se faz da vida finita que se tem nas mãos. É isso o temos. É isso o que somos. Uma finitude com gosto de infinito. Nela a sexualidade nos (e)terniza. 